\title{
Growth and Yield of Ashwagandha [Withania somnifera (L.)] as Influenced by Different Intercropping System in Kymore Plateau of Madhya Pradesh
}

\author{
S.K. Ahirwar ${ }^{1}$, K.K. Agrawal $^{2}$ and H.S. Kushwaha ${ }^{3}$ \\ ${ }^{1}$ Jawaharal Nehru Krishi Vishwa Vidhyalaya, Krishi Vigyan Kendra, Chhindwara \\ 480003 Madhya Pradesh, India \\ ${ }^{2}$ Department of Agronomy, College of Agriculture, Jawaharal Nehru Krishi Vishwa \\ Vidhyalaya, Jabalpur 480004 Madhya Pradesh, India \\ ${ }^{3}$ Mahatma Gandhi Chitrakoot Gramodaya Vishvavidhyalaya, Chitrakoot, Satna, \\ 485334 Madhya Pradesh, India \\ *Corresponding author
}

\section{Keywords \\ Intercropping \\ system, \\ Ashwagandha, Oilseed and Pulses \\ Article Info \\ Accepted: \\ 07 March 2019 \\ Available Online: \\ 10 April 2019}

\section{A B S T R A C T}

The experiment was conducted at the Research farm, Jawaharlal Nehru Krishi Vishwa Vidhyalaya, Jabalpur (MP) during Kharif 2009 and 2011 with a view to study "Effect of different intercropping system on growth and yield of ashwagandha [Withania somnifera (L.)] in Kymore Plateau of Madhya Pradesh". Showed that the plant height did not differ between different treatments at early stage (30 DAS) but at maturity stage, it attained significantly taller plants when intercropped with red gram during both years. Ashwagandha at early (30 DAS) as well as maturity stage was almost unaffected by the maximum branches 1.30 and 5.35 in ashwagandha grown with green gram (3:1). LAI was not-significantly affected due to intercropping system with varied row ratio (3:1 and 4:1). Though, it attained maximum 5.18 at 120 DAS. Plant dry weight was found at peak growth period of ashwagandha viz. 60 and 120 DAS was significantly higher in ashwagandha sole, Ashwagandha + red gram (3:1 and 4:1), Ahawagandha + niger (4:1). The significantly produced higher root yields $(518 \mathrm{~kg} / \mathrm{ha})$ over all other intercropped stands producing tuber yields between 392 to $430 \mathrm{~kg} / \mathrm{ha}$. Amongst the intercropping systems, ashwagandha grown with the sesame (4:1) gave the highest root yield of 430 $\mathrm{kg} / \mathrm{ha}$. Ashwagandha equivalent yield was recorded significantly maximum under ashwagandha + red gram in 3:1 and 4:1 row proportion 6.27 and $6.25 \mathrm{~kg} / \mathrm{ha}$ which exhibited statistically at par with sole Ashwagandha (609 kg/ha).

\section{Introduction}

Ashwagandha [Withania somnifera (L.)] is known as Indian ginseng, poison gooseberry or winter cherry belongs to family Solanaceae and is a cross pollinated crop with chromosome number of $2 \mathrm{n}=48$ (Nigam and Kandalkar, 1995). It is grown mostly on marginal lands of Neemuch and Mandsaur districts of Madhya Pradesh and Kota, 
Jhalawar, Pratapgarh, Chittorgarh and Baran districts of Rajasthan. It has an erect branching under shrub reaching about 0.5- 1.0 $\mathrm{m}$ in height. The main active constituents of ashwagandha plant are alkaloids and steroidal lactones. The important chemical constituents (Withanolides) are present in roots, leaf and berries. The dried roots of ashwagandha have been employed as valuable source of active medicinal ingredients in Indian traditional systems of medicine: Ayurveda, Siddha and Unani. It forms essential constituent or whole of 100 medicinal formulations of traditional pharmacies like Ayurveda, Unani and Sidha (Tuli and Sangwan, 2009). The roots of the plant are categorized as rasayanas, functions as a tonic for vitality and longevity (Singh et $a l ., 2010)$ and have been used as antioxidant, adaptogen, aphrodisiac, liver tonic, antiinflammatory agent, astringent and more recently to treat ulcers, bacterial infections, venom toxins, senile dementia, hiccups, bronchitis, rheumatism, dropsy, several female disorders, stomach and lung inflammation, skin diseases, asthma, emaciation, insomnia, neurological disorders, Parkinson's disease. Intercropping is the production system which provides greater yield on a given piece of land by making more efficient utilizations of the available growth resources using a mixture of crop of different rooting ability, canopy, structure height and nutrient requirement based on the complementary utilization of the growth resources by the component crop. Better use of soil nutrients can be possible due to difference in rooting pattern which may also occur due to mutual avoidance of different rooting system (Trenbath, 1974). With a view to study different intercrops with ashwagandha and its effect on growth and yield, the following experiment was taken up.

\section{Materials and Methods}

The experiment was conducted at the Research Farm of Jawaharlal Nehru Krishi
Vishwa Vidhiyalaya, Jabalpur (MP) during kharif of 2009 and 2011. The soil was clayloam with neutral reaction, low in organic carbon $(0.48 \%)$, available nitrogen (230.2 $\mathrm{kg} / \mathrm{ha}$ ), medium in available phosphorus $(13.80 \mathrm{~kg} / \mathrm{ha})$ and high $(371.70 \mathrm{~kg} / \mathrm{ha})$ in available potassium. The rainfall received was 1471 and $1712 \mathrm{~mm}$, in 43 and 59 rainy days, the mean maximum and minimum temperature were $31{ }^{\circ} \mathrm{C}$ and $30{ }^{\circ} \mathrm{C}$ and $19{ }^{\circ} \mathrm{C}$ and $18{ }^{\circ} \mathrm{C}$, the relative humidity ranged from 52 to $87 \%$ and 55 to $61 \%$ during two respective experimental period. The component crops should invariably having different growth rhythms and rooting patterns were viz. red gram [Cajanus cajan (L) Millspp], and green gram (Vigna radiata Wilczek) as well as oilseed crops viz sesame (Sesamum indicim (L), niger [Guizotia abyssinica (L.F.)] and soybean (Glycine max (L.) Merr.) used with ashwagandha under Kymore Plateau of Madhya Pradesh.

The 11 treatments included viz. Ashwagandha sole $\left(\mathrm{T}_{1}\right)$, Ashwagandha + Red gram 3:1 rows $\left(\mathrm{T}_{2}\right)$, Ashwagandha + Green gram 3:1 rows $\left(\mathrm{T}_{3}\right)$, Ashwagandha + Soybean 3:1 rows $\left(\mathrm{T}_{4}\right)$, Ashwagandha + Sesame 3:1 rows $\left(\mathrm{T}_{5}\right)$, Ashwagandha + Niger 3:1 rows $\left(\mathrm{T}_{6}\right)$, Ashwagandha + Red gram 4:1 rows $\left(\mathrm{T}_{7}\right)$, Ashwagandha + Green gram 4:1 rows $\left(\mathrm{T}_{8}\right)$, Ashwagandha + Soybean 4:1 rows $\left(\mathrm{T}_{9}\right)$, Ashwagandha + Sesame $4: 1$ rows $\left(\mathrm{T}_{10}\right)$ and Ashwagandha + Niger $4: 1$ rows $\left(\mathrm{T}_{11}\right)$ combinations of four replications in RBD. The variety and seed rate of Ashwagandha, red gram, green gram, soybean, sesame and niger were JA 134, $05 \mathrm{~kg}$ / ha; ICPH 2671, 10 kg/ha; K-851, $25 \mathrm{~kg} / \mathrm{ha}$; JS 97-52, $50 \mathrm{~kg} / \mathrm{ha}$; JTS 8, $02 \mathrm{~kg} / \mathrm{ha}$ and JNC 1; 02, kg/ha, respectively, with the spacing between sole ashwagandha and intercrops $30 \mathrm{~cm}$ apart. The seeds were sown on 26 June, 2009 and 30 June, 2011. The recommended dose of fertilizers was $40 \mathrm{~kg} \mathrm{~N}+20 \mathrm{~kg} \mathrm{P}_{2} \mathrm{O}_{5}+20 \mathrm{~kg}$ $\mathrm{K}_{2} \mathrm{O}$ /ha for the Ashwagandha, sesame, and niger, while it was $20 \mathrm{~kg} \mathrm{~N}+60 \mathrm{Kg} \mathrm{P}_{2} \mathrm{O}_{5}+20$ 
$\mathrm{kg} \mathrm{K}_{2} \mathrm{O} / \mathrm{ha}$ for red gram, green gram and soybean. The fertilizer was applied as per plant population of Ashwagandha and component crops. Two irrigations were applied in Ashwagandha and red gram due to escape of rainfall in month of October during the both years. The crops were harvested on different date as per maturity. Those are ashwagandha, red gram, green gram, soybean, sesame and niger 27 Dec, 27 Nov, 29 Aug., 15 Oct, 25, Dec, 20 Oct in 2009 and 28 Dec, 29 Nov, 30 Aug., 17 Oct, 27, Dec, 22 Oct in 2011, respectively. The Ashwagandha was dug out by khurpi to protect the damage of tuber.

The average annual average rainfall through south- west monsoon for the last 20 years is $1350 \mathrm{~mm}$ with maximum concentration of rains during July and August months coupled with intermittent dry spells. The maximum temperature reaches up to $45{ }^{0} \mathrm{C}$ during May and June months, while minimum temperature goes down to the limit of $2{ }^{0} \mathrm{C}$. The relative humidity ranged between 90$100 \%$ during rainy season, which changes as 60 to $70 \%$ and 30 to $40 \%$ during winter and summer seasons, respectively. The weather conditions viz. maximum and minimum temperature, relative humidity, rainfall, sunshine and wind velocity etc prevailed in the locality during the period of investigation were recorded from the Meteorological Observatory located at College of Agricultural Engineering, JNKVV, Jabalpur (M.P.). The values are given in Figure 1, 2 and 3. It is obvious from the data on weather conditions of the locality that there was almost congenial conditions for the germination, growth, development and yield of crop (s) grown under the field experiments during the year 2009-10. But there was high rainfall with much rainy day and least sunshine during the period (meteorological weeks 28 to 32) of germination and an establishment of crops in the year 2010-11.
This resulted in failure of the crops grown in the field. Therefore, the experiment was repeated next year i.e. 2011-12.

Data recorded on economic yields of various crops on weight basis are not directly comparable with each other. Therefore, Ashwagandha equivalent yields (AEY) were determined for all treatments to make them comparable with each other. For this purpose, the economic yields different associated crops were converted in to Ashwagandha economic yields on the basis of existing market value of respective crop components. After this, the converted AEY of associated crop of a particular treatment was added with its Ashwagandha yield realized as a main crop. Finally, AEY values of all treatments were used to compare the effect of the treatments.

$\mathrm{AEY}=$

Yield of Ashwagandha +Seed Yield of Intercrop (IC) kg/ha X Sale Price IC (Rs/kg)

Sale Price of Ashwagandha (Rs/q)

\section{Results and Discussion}

\section{Growth parameters}

The data on various parameters given in table 1 , indicated that plant height did not differ significantly between different treatments at early stage (30 DAS), but at maturity stage, it attained significantly taller plants when intercropped with red gram during both years in consistent manner. Intercropping of Ashwagandha + red gram resulted in the significantly higher plant height of Ashwagandha. However, sesame and niger with ashwagandha also led to increase the plant height of Ashwagandha, and treatment was inconsistently significantly in both years. Branches per plant of ashwagandha was almost totally unaffected by introducing any 
of the crops viz red gram, green gram, soybean, sesame and niger over sole cropping at early (30 DAS) as well as maturity stages. The number of branches/plant of Ashwagandha ranged from 1.17 to 1.28 and 5.18 to 5.35 between different intercropping system at 30 DAS and maturity stages, respectively. Growth parameters viz. plant higher and number of branches of Ashwagandha was recorded at early growth and maturity stages, from the results it is evident that plant height and branches/plant did not differ with each other due to the effect of different intercropping systems. The dry matter of Ashwagandha under sole and with some of intercrop was almost same or not significantly influenced due to intercropping system and varied row ratio. None of intercrops grown with ashwagandha caused any remarkable negative influence on utilization of light and space by the ashwagandha. Besides these, the nutrient and moisture requirement of almost all intercrops quite resembled to Ashwagandha. Therefore above mentioned both growth parameter of Ashwagandha in all intercropped stand were on par to its sole stands. Similar opinion about unaffected growth of Ashwagandha under intercropping system in replacement series have been reported by workers from their studies. These findings are in accordance with those of several workers (Willey, 1979, Maurya and Rathi, 2000).

\section{Leaf area index}

Leaf area index (LAI) values successively increased due to advancement in the growth stages of crop up to 120 DAS (5.18) and then it showed declining trend upto maturity stage. It is also apparent from the data that rate of increment in LAI values was most rapid during the period between 60 DAS to 120 DAS and thereafter it slowed decline till the maturity. Intercropping of companion crops viz. red gram, green gram, soybean, sesame and niger with Ashwagandha in 3:1 as well as 4:1 row proportions did not show any remarkable change in LAI values of Ashwagandha over its sole stand at any of the growth stages during both years of investigation. Ashwagandha + red gram/ niger recorded numerically higher LAI at all stages of crop.

\section{Dry weight of plants/m²}

Dry matter accumulation by the ashwagandha plants gradually increased at a steady rate up to the maturity of the crop under all treatments with the rapid rate increment after 90 DAS growth stage. There were significant variations in dry matter accumulation by Ashwagandha under different treatments. At 30 days stage, significantly superior dry matter was noted in Ashwagandha + soybean under both the row proportion $\left(89 \mathrm{~g} / \mathrm{m}^{2}\right)$ followed by sole Ashwagandha and Ashwagandha + red gram (1:3 row ratio). However, at 60 days stage, it was observed significantly higher in Ashwagandha + green gram (4:1) followed by sole Ashwagandha and Ashwagandha + niger (4:1). Similarly, at 90 days, dry matter pattern was slightly changed and it observed significantly greater and same under Ashwagandha sole, Ashwagandha + green gram (3:1), Ashwagandha + sesame (3:1) and Ashwagandha + niger $(4: 1)$ followed by Ashwagandha + green gram (4:1). At 120 days stage, significantly maximum dry matter was noted in Ashwagandha sole, Ashwagandha + niger (4:1) and Ashwagandha + red gram. While at 150 days and at maturity its dry matter accumulation was not varied significantly due to intercropping and row proportion pattern. It means growth of Ashwagandha up to 90 days stage was changed almost in same pattern under both 3:1 and 4:1 row proportions of intercrops. Leaf area index (LAI), crop growth rate (CGR), relative growth rate (RGR) and net 
assimilation rate (NAR) is known as growth analysis parameters. Crop production is the practical means of tapping solar energy (sunlight) and converting it into food and other useable material through the production of leaves. The surface area of leaves per plant is an important determinant in the production of photosynthes suggested (Watson, 1952).

The maximum LAI was recorded in Ashwagandha with red gram. This might be owing to the better availability and utilization of nutrients with presence of green gram and thereby effective conversation of multi nutrients at the site of photosynthesis into pigments (Sanjutha et al., 2008). In fact most favorable soil condition might have produced maximum photosynthetic accumulation towards leaf biomass, because during initial stage, leaf is the most powerful sink than any other plant parts in most of the crops (Table 2).

\section{Yield attributing parameters}

\section{Length of roots}

Length of roots of Ashwagandha was not varied significantly due to intercropping treatments. Root length varied from 12.20 to $13.20 \mathrm{~cm}$ during first year (2009-10) of investigation, which were almost similar in the next year (2011-12) as 12.15 to $13.00 \mathrm{~cm}$ also. Based on two years mean data, the root length ranged between 12.18 to $13.08 \mathrm{~cm}$.

\section{Diameter of roots}

Diameter of roots of Ashwagandha as also did not significantly differ with each other. Though, the values of diameter of roots were numerically greater in sole stand of crop over its other intercropped stands. The values pertaining to diameter of roots ranged between 2.54 to $2.96 \mathrm{~cm}$ and 2.45 to $2.87 \mathrm{~cm}$ in the two consecutive years of investigation. On the basis of 2-year data, the mean root length varied from 12.18 to $13.08 \mathrm{~cm}$ and root diameter from 2.60 to $2.89 \mathrm{~cm}$ at harvest stage, of ashwagandha were augmented nonsignificantly due to ashwagandha grown alone as well as intercropped with legumes and oilseeds (Table 3). The other intercropping treatment was resulted in non-significantly lower values of root parameters. The significantly higher values of root parameters under Ashwagandha grown sole might be owing to increased vegetative growth including leaves surface or photosynthetic area producing more photosynthesis for root growth and shoot development of ashwagandha. In comparison to other ten intercrops, green gram legume crop benefitted ashwagandha in several ways due to its better compatibility with the main crop. The variation in the development of roots and shoots of different intercrops is governed by their genetic architecture of parents. The results corroborate with those of (Shrivastava et al., 2004 and Lingaraja et al., 2008).

\section{Productivity of Ashwagandha}

\section{Root yields}

Ashwagandha is mainly grown for its root yields. It is evident from the data of table 3, that root yields of Ashwagandha significantly varied between different treatments in both years of investigation as well as for mean yields of both years. The trend of root yields was almost similar in both years under different treatments. Based on 2 years mean data, sole crop of Ashwagandha significantly produced higher root yields $(518 \mathrm{~kg} / \mathrm{ha}$.) over all other intercropped stands producing root yields between 392 to $430 \mathrm{~kg} / \mathrm{ha}$. The variations in root yields between different intercropped stand were not significant, but intercropping of all associate crops with Ashwagandha in row proportions led to record consistently higher root yields than those obtained with respective associate crop in 3:1 row proportion. 
Table.1 Plant height (cm.) and Number of branches of Ashwagandha as affected by different intercropping systems (pooled data of 2 years)

\begin{tabular}{|c|c|c|c|c|c|c|c|c|c|c|c|c|}
\hline \multirow[t]{2}{*}{$\begin{array}{c}\text { Treatment } \\
\text { s }\end{array}$} & \multicolumn{3}{|c|}{$\begin{array}{c}\text { Number of branches } \\
\text { at } 30 \text { DAS }\end{array}$} & \multicolumn{3}{|c|}{$\begin{array}{c}\text { Number of branches } \\
\text { at Maturity }\end{array}$} & \multicolumn{3}{|c|}{$\begin{array}{c}\text { Plant height (cm.) at } \\
30 \text { DAS }\end{array}$} & \multicolumn{3}{|c|}{$\begin{array}{c}\text { Plant height (cm.) } \\
\text { at Maturity }\end{array}$} \\
\hline & 2009 & 2011 & Mean & 2009 & 2011 & Mean & 2009 & 2011 & Mean & 2009 & 2011 & Mean \\
\hline $\mathbf{T}_{1}$ & 1.30 & 1.25 & 1.28 & 5.22 & 5.25 & 5.24 & 6.75 & 6.75 & 6.75 & 49.75 & 52.00 & $\mathbf{5 0 . 8 7}$ \\
\hline $\mathbf{T}_{2}$ & 1.25 & 1.20 & 1.23 & 5.30 & 5.25 & 5.28 & 6.25 & 6.25 & 6.25 & 56.75 & 51.50 & 54.13 \\
\hline $\mathbf{T}_{3}$ & 1.34 & 1.25 & 1.30 & 5.44 & 5.25 & 5.35 & 6.50 & 6.25 & 6.37 & 50.50 & 50.25 & 50.38 \\
\hline $\mathbf{T}_{4}$ & 1.20 & 1.20 & 1.20 & 5.10 & 5.32 & 5.21 & 6.50 & 6.00 & 6.25 & 49.50 & 52.75 & 51.12 \\
\hline $\mathbf{T}_{5}$ & 1.15 & 1.25 & 1.20 & 5.20 & 5.30 & 5.25 & 6.25 & 6.25 & 6.25 & 47.25 & 48.00 & 47.62 \\
\hline $\mathbf{T}_{6}$ & 1.20 & 1.20 & 1.20 & 5.25 & 4.18 & 4.72 & 6.50 & 6.10 & 6.05 & 47.00 & 48.00 & 47.50 \\
\hline $\mathbf{T}_{7}$ & 1.10 & 1.25 & 1.18 & 5.15 & 5.25 & 5.20 & 6.25 & 6.25 & 6.25 & 53.75 & 54.75 & 54.25 \\
\hline $\mathbf{T}_{8}$ & 1.25 & 1.20 & 1.22 & 5.35 & 5.35 & 5.35 & 6.75 & 6.25 & 6.50 & 48.50 & 50.75 & 49.63 \\
\hline $\mathbf{T}_{9}$ & 1.15 & 1.20 & 1.17 & 5.25 & 5.32 & 5.29 & 6.50 & 6.50 & 6.50 & 49.00 & 50.00 & 49.50 \\
\hline $\mathbf{T}_{10}$ & 1.25 & 1.25 & 1.25 & 5.20 & 5.25 & 5.23 & 6.45 & 6.50 & 6.45 & 52.00 & 53.25 & 52.63 \\
\hline $\mathbf{T}_{11}$ & 1.15 & 1.25 & 1.20 & 5.15 & 5.20 & 5.18 & 5.25 & 5.25 & 5.25 & 51.00 & 52.75 & 51.87 \\
\hline SEm \pm & 0.11 & 0.09 & 0.07 & 0.17 & 0.08 & 0.10 & 0.39 & 0.31 & 0.28 & 0.02 & 0.06 & 0.99 \\
\hline CD at $5 \%$ & NS & NS & NS & NS & NS & NS & NS & NS & NS & 0.05 & 1.73 & 2.86 \\
\hline
\end{tabular}

Where, $T_{1}$ (Ashwagandha (A) sole), $T_{2}\left(A+\right.$ Red gram 3:1 rows), $T_{3}\left(A+\right.$ Green gram 3:1 rows), $T_{4}\left(A+\right.$ Soybean 3:1 rows), $T_{5}\left(A+\right.$ Sesame 3:1 rows), $T_{6}(A+$ Niger 3:1 rows), $T_{7}\left(A+\right.$ Red gram 4:1 rows), $T_{8}\left(A+\right.$ Green gram 4:1 rows), $T_{9}\left(A+\right.$ Soybean 4:1 rows), $T_{10}(A+S e s a m e ~ 4: 1$ rows $), T_{11}(A+N i g e r ~ 4: 1$ rows $)$. 
Table.2 Physiological parameters of Ashwagandha under different intercropping systems (Pooled for 2 years)

\begin{tabular}{|c|c|c|c|c|c|c|c|c|c|c|c|c|}
\hline \multirow[t]{2}{*}{ Tt. } & \multicolumn{6}{|c|}{ LAI } & \multicolumn{6}{|c|}{ Plant dry weight $\left(\mathrm{g} / \mathrm{m}^{2}\right)$} \\
\hline & $\begin{array}{c}\text { 30 } \\
\text { DAS }\end{array}$ & $\begin{array}{c}\text { 60 } \\
\text { DAS }\end{array}$ & $\begin{array}{c}90 \\
\text { DAS }\end{array}$ & $\begin{array}{c}120 \\
\text { DAS }\end{array}$ & $\begin{array}{c}150 \\
\text { DAS }\end{array}$ & Maturity & $\begin{array}{l}0-30 \\
\text { DAS }\end{array}$ & $\begin{array}{c}30-60 \\
\text { DAS }\end{array}$ & $\begin{array}{c}\text { 60-90 } \\
\text { DAS }\end{array}$ & $\begin{array}{c}\text { 90-120 } \\
\text { DAS }\end{array}$ & $\begin{array}{c}\text { 120-150 } \\
\text { DAS }\end{array}$ & $\begin{array}{c}150 \\
\text { DAS } \\
\text { maturit } \\
\quad y\end{array}$ \\
\hline $\mathbf{T}_{1}$ & 1.44 & 2.80 & 4.00 & 5.18 & 5.08 & 4.99 & 88 & 190 & 317 & 454 & 589 & 800 \\
\hline $\mathbf{T}_{2}$ & 1.44 & 2.88 & 4.05 & 5.18 & 5.09 & 5.02 & 88 & 184 & 308 & 438 & 590 & 793 \\
\hline $\mathbf{T}_{3}$ & 1.36 & 2.72 & 3.83 & 4.98 & 4.88 & 4.80 & 86 & 189 & 317 & 451 & 589 & 798 \\
\hline $\mathbf{T}_{4}$ & 1.36 & 2.72 & 3.89 & 5.02 & 4.93 & 4.86 & 89 & 187 & 310 & 448 & 590 & 805 \\
\hline $\mathbf{T}_{5}$ & 1.36 & 2.72 & 3.89 & 4.98 & 4.90 & 4.83 & 86 & 184 & 317 & 448 & 591 & 791 \\
\hline$T_{6}$ & 1.36 & 2.80 & 3.89 & 5.05 & 4.95 & 4.88 & 87 & 187 & 305 & 443 & 597 & 804 \\
\hline $\mathbf{T}_{7}$ & 1.36 & 2.72 & 3.89 & 5.02 & 4.91 & 4.83 & 87 & 184 & 310 & 453 & 592 & 805 \\
\hline $\mathbf{T}_{8}$ & 1.36 & 2.72 & 3.89 & 4.98 & 4.90 & 4.82 & 85 & 191 & 315 & 447 & 592 & 791 \\
\hline $\mathbf{T}_{9}$ & 1.44 & 2.80 & 4.00 & 5.12 & 5.02 & 4.94 & 89 & 188 & 312 & 447 & 592 & 801 \\
\hline $\mathbf{T}_{10}$ & 1.36 & 2.72 & 3.89 & 5.02 & 4.93 & 4.85 & 86 & 186 & 309 & 446 & 599 & 803 \\
\hline $\mathrm{T}_{11}$ & 1.44 & 2.88 & 4.05 & 5.18 & 5.09 & 5.01 & 85 & 190 & 317 & 454 & 590 & 807 \\
\hline SEm \pm & 0.01 & 0.02 & 0.05 & 0.05 & 0.01 & 0.02 & 0.28 & 0.40 & 0.70 & 0.80 & 0.85 & 1.85 \\
\hline CD 5\% & NS & NS & NS & NS & NS & NS & 0.80 & 1.16 & 2.02 & 2.31 & 2.45 & NS \\
\hline
\end{tabular}

Table.3 Growth and development of Ashwagandha under different intercropping systems (Pooled for 2 years)

\begin{tabular}{|c|c|c|c|c|c|c|c|c|c|c|c|c|}
\hline \multirow[t]{2}{*}{ Tt. } & \multicolumn{3}{|c|}{ Root length $(\mathrm{cm})$} & \multicolumn{3}{|c|}{ Root diameter $(\mathbf{c m})$} & \multicolumn{3}{|c|}{ Root yield (kg/ha) } & \multicolumn{3}{|c|}{ AEY* (kg/ha) } \\
\hline & 2009 & 2011 & Mean & 2009 & 2011 & Mean & 2009 & 2011 & Mean & 2009 & 2011 & Mean \\
\hline$T_{1}$ & 13.20 & 12.95 & 13.08 & 2.96 & 2.82 & 2.89 & 510 & 525 & 518 & 602 & 617 & 609 \\
\hline $\mathbf{T}_{2}$ & 12.20 & 12.15 & 12.18 & 2.65 & 2.80 & 2.73 & 390 & 410 & 400 & 617 & 636 & 627 \\
\hline $\mathbf{T}_{3}$ & 13.15 & 12.80 & 12.98 & 2.56 & 2.90 & 2.73 & 385 & 408 & 397 & 500 & 516 & 508 \\
\hline $\mathbf{T}_{4}$ & 13.05 & 12.75 & 12.90 & 2.80 & 2.65 & 2.73 & 380 & 413 & 397 & 499 & 527 & 513 \\
\hline $\mathbf{T}_{5}$ & 12.60 & 12.80 & 12.70 & 2.65 & 2.58 & 2.62 & 386 & 420 & 403 & 498 & 527 & 513 \\
\hline$T_{6}$ & 12.65 & 12.75 & 12.70 & 2.54 & 2.80 & 2.67 & 368 & 15 & 392 & 474 & 511 & 493 \\
\hline $\mathbf{T}_{7}$ & 12.60 & 12.75 & 12.68 & 2.75 & 2.65 & 2.70 & 415 & 430 & 423 & 621 & 630 & 625 \\
\hline $\mathbf{T}_{8}$ & 13.05 & 13.00 & 13.03 & 2.83 & 2.87 & 2.85 & 420 & 425 & 423 & 533 & 534 & 533 \\
\hline $\mathbf{T}_{9}$ & 12.75 & 12.80 & 12.78 & 2.75 & 2.45 & 2.60 & 408 & 432 & 420 & 526 & 545 & 536 \\
\hline$T_{10}$ & 12.55 & 12.55 & 12.55 & 2.65 & 2.55 & 2.60 & 425 & 435 & 430 & 535 & 540 & 537 \\
\hline$T_{11}$ & 12.30 & 12.75 & 12.53 & 2.80 & 2.60 & 2.70 & 420 & 430 & 425 & 525 & 530 & 527 \\
\hline S Em \pm & 0.31 & 0.26 & 0.27 & 0.18 & 0.21 & 0.20 & 3.00 & 4.00 & 4.00 & 18 & 40 & 29 \\
\hline CD at $5 \%$ & NS & NS & NS & NS & NS & NS & 9.00 & 12.00 & 11.00 & 52 & 115 & 83 \\
\hline
\end{tabular}


Fig.1 Weekly meteorological observations during the crop season from the year 2009-10

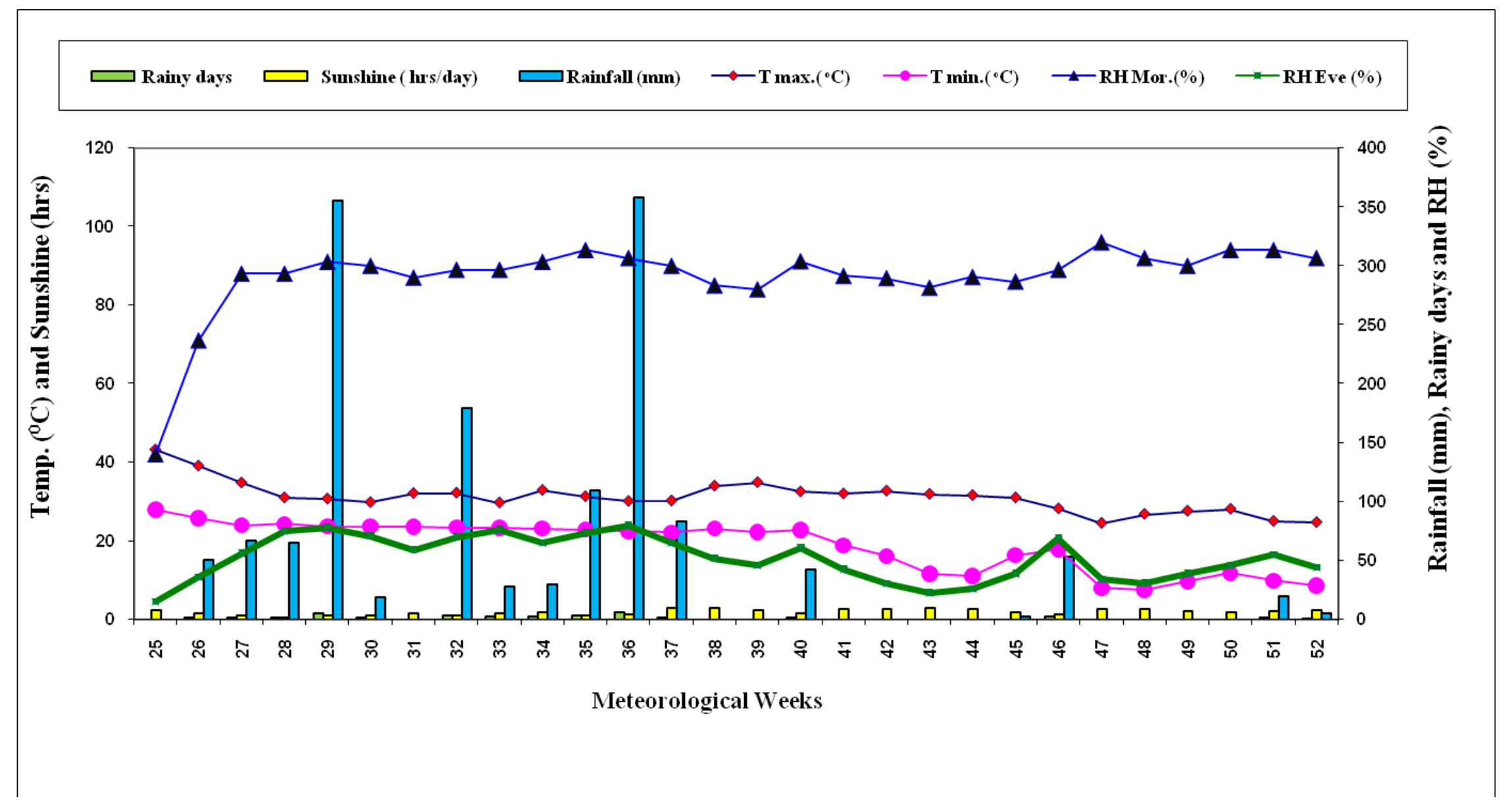


Fig.2 Weekly meteorological observations during the crop season from the year 2010-11

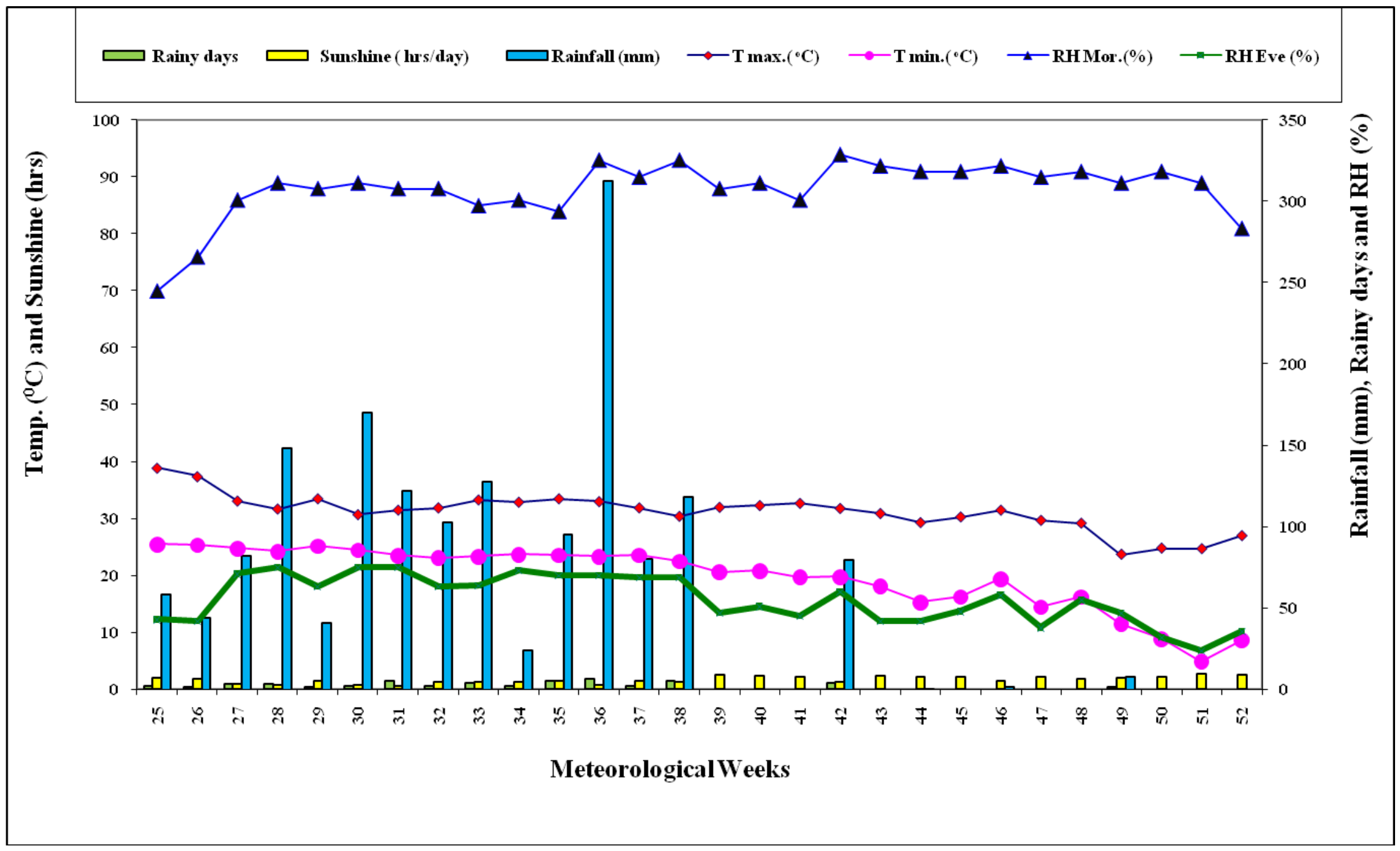


Fig.3 Weekly meteorological observations during the crop season from the year 2011-12

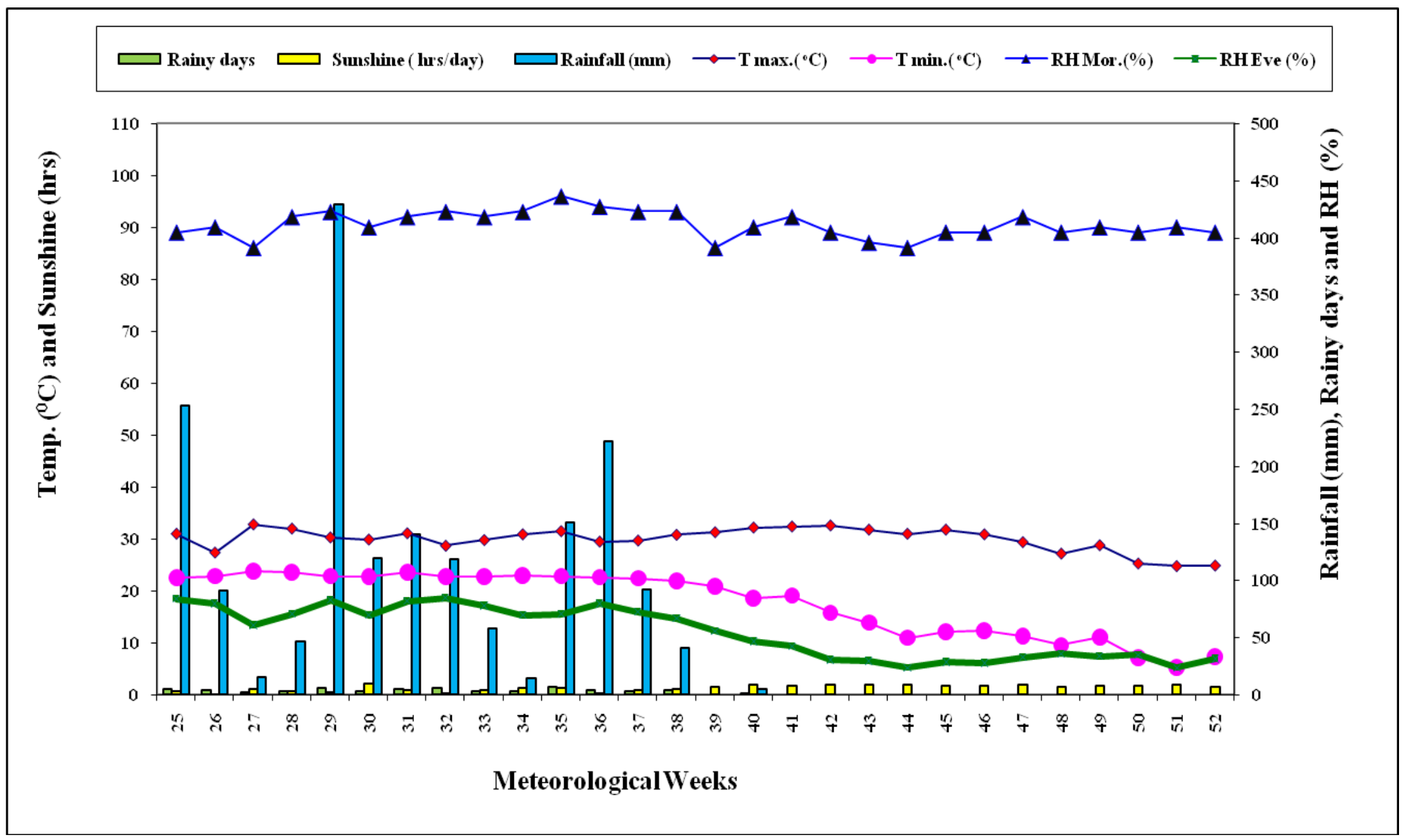


The root yields of Ashwagandha ranged between 420 to $430 \mathrm{~kg} / \mathrm{ha}$ in $4: 1$ row proportions, while it ranged from 392 to 403 $\mathrm{kg} / \mathrm{ha}$ in 3:1 row proportions. Root studies in ashwagandha involve the yield attributing parameters because it is a root crop used as a medicine. In the present study range of root length and root diameter were augmented non-significantly due to Ashwagandha grown alone as well as intercropped with legumes and oilseeds. The findings corroborate with those of Shrivastava et al., 2004 and Lingaraja et al., 2008.

\section{Ashwagandha Equivalent Yield (AEY)}

The AEY significantly varied between different intercropping treatments during both years of investigation as well as mean of the 2-year data (Table 3). Based on mean data of both years, Ashwagandha + red gram intercropping system led to record AEY of 627 and $625 \mathrm{~kg} / \mathrm{ha}$ in $3: 1$ and $4: 1$ row proportion, respectively which was numerically higher than sole Ashwagandha stand $(609 \mathrm{~kg} / \mathrm{ha})$. The advantage of seed yield of red gram replacing one row of ashwagandha either of $3: 1$ and $4: 1$ row proved to be better than sole cropping of ashwagandha as well as its intercropping with pulse (green gram) and oilseed (soybean, sesame and niger) crops. The mutual cooperation of ashwagandha and red gram for their co-existence and higher market value of red gram in the market appears to be possible reason for its intercropping. The results are also corroborated with the finding of several other research workers (Patra et al., 1990, Sarkar, Shit et al.,1990, Pannase and Sharma 2009, Rout et al., 1990, Andrade et al., 2001, Sunil Kumar et al., 2003, Kurmvanshi and Rathore 2010 and Verma et al., 2005).

In conclusion, on the basis of two year data of field experiment it is entered that productivity of ashwagandha intercropped with pulse and oilseeds under 3:1 and 4:1 row ratios of Ashwagandha + red gram was found most productive system and AEYs it is under 3:1 $(627 \mathrm{~kg} / \mathrm{ha})$ and 4:1 (625 kg/ha) which were significantly superior to sole Ashwagandha stand (609 kg/ha). Inter cropping of Ashwagandha + red gram in 3:1 ratio was Rs 129760/ha, with BC ratio of 5.81 followed by 4:1 row ratio (Rs 129037/ha with $\mathrm{BC}$ ratio of 5.74) most profitable system in terms of monetary return and benefit ratio for sustainable production in Kymore Plateau zone and other area having similar climate.

\section{References}

Andrade, M. J. B. de, Morris, A. S. de, Teixeria, I. R. and Silva, M. V. da. 2001. Evaluation of intercropping system under beans and ashwagandha. Indian Journal of Agronomy. 24 (14): 25-28.

Kirtivardha, V. and Ahirwar, S. K. 2009. Effect of yield and economics of Isabagol. International Journal of Plant Archives. 15(2):280-283.

Kurmvanshi, S. M., and Rathore, L. (2010) A study on productivity of redgram and soybean, Agronomy and Research approach. Field Crops. 29 (1\&2): 7075.

Lingaraju, B. S., Merer, S. B. and Chandrashekar, S. S. 2008. Studies on intercropping of maize and pigeon pea under rainfed conditions in Northern Transitional Zone of Karnataka. Karnataka Journal of Agricultural Science, 21(1):1-3.

Maurya, B. M. and Rathi, K. S. 2000. Growth and development of soybean as influenced by intercropping with pigeon pea and phosphorus level. GAU Research Journal, 26(1):1-5.

Nigam, K. B., Kandalkar, V. S. 1995. Ashwagandha - Advances in 
Horticulture, Medicinal and Aromatic plants. Malhorta Publishing House, New Dheli, India. 11: 337-344.

Pannase S. and Sharma, R. S. 2009. Yield and economics of niger in intercropping system. Indian Journal of Agronomy, 35: 122-120.

Rout, D., Pradhan, L., Barik, T. and Misra, S. N. 1990. Studies on pure stand and cereal legume association of maizesorghum cowpea and rice bean in different proportions. Indian Agriculturist, 34: 41-46.

Sanjutha, S., Subramaniam, S., Indu Rani, C. and Maheshwari, J. 2008. Integrated Nutrient Management in Angrographis Peniculata. Research Journal of Agricultural and Biological Science. 4.(2): 141-145.

Sarkar, R. M. and Shit, D. 1990. Effect of intercropping cereals, pulses and oilseeds with maize on production competition and advantage. Indian Agriculturist, 34: 88-89.

Shrivastava, G. K., Lakpale, R., Choubey, N. K. and Singh, A. P. 2004. Productivity and economics of pigeon pea + urdbean intercropping system under various planting geometry and fertilizer management in rainfed condition of Chhattisgarh. Indian Journal of Agronomy, 49 (2): 101-103.

Singh G., Sharma, P. K., Dudhe, R. and Singh, S. 2010. Biological activities of Withania somnifera. Scholars Research
Library, 1:56e 63.

Sunil Kumar, Rawat, C. R. and Melkania, N. P. 2003 Intercropping of forage sorghum in pigeon pea under rainfed conditions in semi-arid region. Range Management and Agroforestry, 24 (2): 143-147.

Trenbath, B. R. 1974. Biomass productivity of mixtures. Advances in Agronomy, 26: $177-206$

Tuli, R. and Sangwan, R. S. 2009. Ashwagandha a model Indian medicinal plantl. Council of Scientific and Industrial Research (CSIR), New Delhi.

Verma, S. S, Joshi, Y. P. and Saxena, S. C. 2005. Effect of row ratio of fodder sorghum in pigeon pea intercropping system on productivity, competition functions and economics under rainfed conditions of north India. Indian Journal of Agronomy, 50: 123-125.

Watson, D. J. 1952. Physiological basis of variation in yield. Advances in Agronomy, 4:101-145.

Willey, R. W. 1979. Intercropping, its importance and research needs part 2. Agronomy and Research approach. Field Crops Abstract, 32 (1\&2): 1-10 and 73-85.

Yadav, M. K, Kushal, P. L. and Khurana, S. L. 2011. Effect of intercropping of pulses and oilseeds with Ashwagandha on production. Indian Agriculturist, 19:18-20.

\section{How to cite this article:}

Ahirwar, S.K., K.K. Agrawal and Kushwaha, H.S. 2019. Growth and Yield of Ashwagandha [Withania somnifera (L.)] as Influenced by Different Intercropping System in Kymore Plateau of Madhya Pradesh. Int.J.Curr.Microbiol.App.Sci. 8(04): 513-524. doi: https://doi.org/10.20546/ijcmas.2019.804.056 